\title{
Advance Fundraising Techniques: An Evidence from Non-Profit Organizations
}

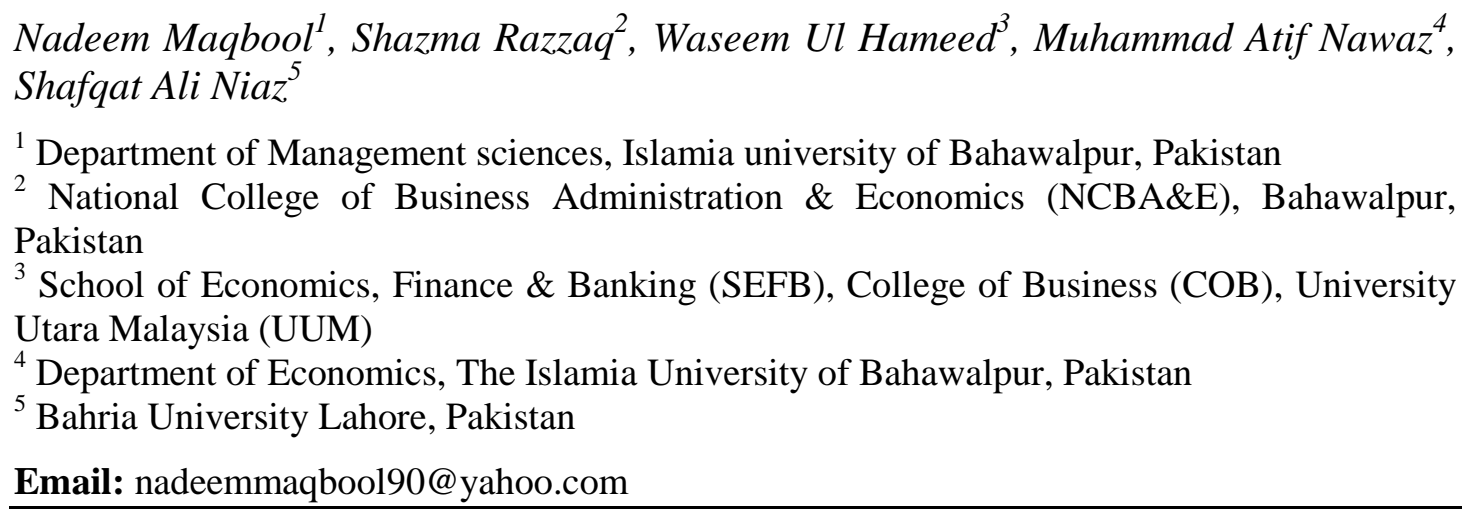

\begin{abstract}
The purpose of this research study is to explore the advance fundraising techniques in the non-profit, charitable, philanthropic organizations for the purpose of fundraising. This research study completed on the basis of primary data that is taken from NGO's in the region of Punjab. Frequency distribution statistical technique is used in this research paper for analyzing the data. Data collection was completed through questionnaire, face to face interviews, telephonic interviews, survey through e-mails from the presidents of the non-profit organization and members of NGO which are working in the Punjab region. NGO's such as Alpine Welfare, Umeed Welfare, People Woman Welfare Organization, Human development Form etc. were contacted for data collection. Fundraising is the management function. After the research we would be able to understand the advance fundraising techniques and methods. We have found the positive impact of technological media like YouTube, Face book, Twitter, and TV campaigns on the fundraising. In this research it is found that how donor's relationship can create for fundraising. This research helps to the fundraiser for the fund generating. It gives a way to nonprofit charitable organization to increase their worth of money. The application of this research provides fundraising managers that is the good for any organization profitable or nonprofit able organizations.
\end{abstract}

Keywords: Fundraising techniques, Donors communication, charitable organization, NGOs. 


\section{Introduction}

Fundraising is the process of gathering money by charitable organization for the welfare of the society. Fundraising is an essential for the survival of the society when there is a low support from the government. A large number of these organizations are human services nonprofits employing social workers and providing mental health, housing, and other types of basic direct services to clients needing assistance (Hoefer, 2012). This study is one of the attempt to explore variables which have impact on fundraising. This research finds the advance fundraising techniques, strategies in the non-profitable organizations. In the modern age social media and internet use is growing. The aim of this research study to see the positive and negative effect of advance fundraising techniques on the NGO's fund. As the funds are most import for every business (Hameed, Mohammad, \& Shahar, 2018; Maqbool, Hameed, \& Habib, 2018). Literature review shows the arguments of the researchers about the fundraising dependent and independent variables and differentiates each other with their effect on fundraising. It also highlights religious aspect which more important (Conway, \& Price, 1998). In theoretical frame-work variables are faith base organization, social media, special events, tragic events, e-philanthropy, joint collaboration, proposal writing, street solicitation, corporate sponsorship and donor relationship. This research study tests the hypotheses based on the relationship between these variables and fundraising.

This research paper study examines and explores the advance fundraising techniques and their impact on the nonprofit organization. The purpose of this research paper is to give awareness of fundraising principals to the fundraisers. The principal take money to make money is generally accepted in the profitable organization, but it is not necessary in the nonprofit, charitable organizations. Why?

Donor relationship can create with the strong branding of the welfare organizations and strong barding is being done through the social media and with new technology of media advertisement appeal and with the help of modern web-based technology, moreover, it can increase the donation (Farquharson, 1994). However, the study points out the questions; individual and corporate donors how can attract for the donations? What should use strategies to increase charity in the non-governmental organizations? Faith based organizations such Muslim or Christian base organizations can how increase their findings? This research literature gives all the above question answers. Finance can be defined as creation, management, allocation and study of the money. In this research study first section based on finding that how NPO's fundraising or create the fund for their organization. 


\section{A. Faith Base Organization}

\section{Literature Review}

Most of the researches show that faith affects the fundraising in the organization. In the faith base organization peoples are motivated by the faith due to this they give more money, charity to that type of organization. Faith base organization (FBO) mostly is based on the religious. FBO's removes the social isolation and works for the societal integration. FBO's helps to the poor people in the society and provide services in the disaster. All of the above services faith base organization they get the trust of the donors, therefore, they give charity with generously to these organization (Ashely, 2012).

Fundraising is a basic task of NGO's and for the nonprofit organizations. Fundraiser use religious text to generate the fund its technique to take the charity from the religious communities. In the religious context there are the following two religious organizations are being discuss first is Muslims faith base organization's or in other words you can say that Islamic relief organization and second one is Christian faith base organizations. Muslims FBO's support to the needy and poor people, these organization generate fund by the Zakat and search out the donors that want to give Zakat to poor people. It's a charity system in the Muslim economy. Christen community peoples give charity form their income to the churches and to christen faith base organization for the worship of Juses. Some churches give donation for the international level projects (Ashely, 2012).

\section{B. Social Media}

Social media is another fundraising technique that is used to create relationship between organization's people and donors due to the quick information flow and network organization generate more funds. For the purpose of fundraising, there are the following social media tools are used like Twitter, Facebook, YouTube, E-newsletter, E-mails and Skype. From all of the above social media tools organization searches the donors and nonprofit organization make a brand image in the eyes of public. Because public support to these organization for the survival of the society (Boyer, 2011).

Social media is a new concept for effective fundraising. It creates awareness, twoway communication and built public relation. Khalo Culture Center is a fundraising nonprofit organization that is being use facebook for fundraise purposes, approximately $80 \%$ of the users are registered by the facebook for the online fund generation. Face book is a social media tool that is used for social networking these blogs and websites provides information to the users about the nonprofit organization, moreover, these tools are user friendly. Due to the 
growth of social media traditional donations methods are also growing (Boyer, 2011). Accountability of non-profitable organization is being done through the media and social media is also affecting their image in the society (Unerman \& O'Dwyer 2006). NGO's analysis can be through the photography and can check the accountability (Davison, 2005).

Fundraising in the libraries is growing in this modern age through the technological advancement and social media such as Facebook and YouTube provide awareness about recognize the donors. Social media is another approach for attracting the donors; fundraisers search the digital donor through engagement with public. In libraries' digital bookplates provides identification of supporters or donors and gifts, aid, and donation from the other campuses (Foster, 2012).

All around the world digital social media creates relationship with donor's. The online nature of the digital bookplate program has also allowed Western Libraries to extend relationships with donors around the globe. For fundraising in libraries' digital bookplates pays important role to get the fund, charity, gifts, donation at international level (Foster, 2012).

Newsletter is also a technique of collection of funds readers of newsletter helps in terms of cash. It is difficult to search out the donors from a large number of individual and create better relation and meaningful relationship with donors, for this purpose, virtual media pays important role for fundraising (Silverman, 2009).

Nonprofit origination's use these websites Facebook, Twitter, E-newsletters and YouTube for the achievement of their organizational goals. Nonprofit organizations are connected with public through this social networking. Different researches show that most of the fundraisers progress is growing due to use of internet social sites ( e.g. Facebook) and these fundraising foundations are becoming successful for generating fund more and more (Branston, YMCA, \& Bush, 2010).

\section{Relationship with Donor}

For decision making about the donation, how donors receive messages of fundraising and how respond to fundraising messages? Now a day's Fundraisers are using new techniques like 'psychological factors to increase their funding. Previous researches show that messages of funding provide potential donors for donation. There are the categories of reward that is given to the donors which are social, emotional and economic (Brand, 2010). Different researches show the information about why donor's want to give donations. According to some researchers concluded that donors donate most of the fund because they or their close 
ones have faced the problems of funds. And now they want to remove the fund problem for the needy peoples (Brand, 2010).

Fundraiser use strategies and make plan for the purpose of successful fundraising. For example, different fundraisers for the purpose of purchasing new home they save some money from their salary which is the fundraising strategy. When donors receive gifts and benefit from the non-profit organization they feel good and their motivation level increase for donating and they try to give more charity to these organizations (Brand, 2010).

International donors do some agreements to these NGO'S and with nonprofit organization for the donation which is another source of increasing the NGO'S wealth. Received the most aid from across the country papers customize fundraising, emphasizing local support, the development of NGO importance of the project. Still attractive to prospective overseas donors know they have it in mind to support the project also encourages donations from around the country. Therefore, it is not ignored the possibility of contributions received from the country to obtain money or supplies (Ciucescu, 2012).

\section{Sophisticated Technology Tools}

Advance technology tools help to the NGO's members for the good communication with donors. These tools play an important role in fundraising for their nonprofit organization. Internet is a best tool for fundraising companies and technology that is being use in this age of science. Blogs, e-mails websites, telecommunication, electronic media, television and radio are major technology tools for fundraising (Neale, 2011). After analyzing the surveys and interviews, advocates of finance describe that funding text is the best tool to convey the messages for fundraising to the donors or target population. Nonprofit organization funds are affecting due the funding text messages (Nichols, 2008).

\section{E. Events}

Growth of fundraising is also based on the following events such as tragic events, special events, concerts events, sports events, dinners, galas a concert events are the fundraising tools for the nonprofit organization (Leighann Neilson, 2012). Fundraisers promote these events with different ways of advertisement admin and researchers of nonprofit organization analyze the past fundraising techniques in special events and take decision for future fundraising (Leighann Neilson, 2012).

Without donor recognition fundraising cannot be done so for the recognition of donors. There are the following ways more necessary for fund generation. Yearly meetings, 
identification of opportunities, annual reports, create public awareness through media, sponsorship events (Edwin, 1998).

Fundraiser invite to the donors in the special events in which gifts are distributed to the donors in the nonprofit organization's due this activity fundraisers are doing analysis of the donors liking and disliking so that that can improve their fundraising for the future findings (Waters, 2010).

Social welfare and nonprofit organizations working increase and decrease in the tragic events like 9/11 attacks, earthquake and disaster. After the issue of 9/11 attacks Islamic non-profit organizations face more challenges based on the allegation that Islamic charitable organizations are sporting to the terrorism, therefore, funding from the foreign countries decline to the Islamic charitable organizations (Ashely, 2012).

\section{F. Joint Collaboration}

There is only one solution for quick fundraising which is friend of library joint collection. Fundraising opportunities can be increase by the combined group effort and with the joint collaboration (Neale, 2011).

\section{G. Philanthropy/ Humanity}

In the US economy charity organization is growing because these organizations are tax exempt and these organizations are generating more funds from the society for the welfare of the society. These organizations use different strategies to influence the people and convey their message to every donor with the utilization of technological advancement (Brand, 2010). Partnership is requiring in the NGO's for the potential financial management. Private sector partnership is used in the nongovernmental organizations for the corporate social responsibility (Borwanker, 2007). Fundraising of organizations is depending on the effective messages of fundraising that is delivering to the donors (Kuiper, Das, \& Kerkhof, 2008).

\section{Dependent Variable}

\section{H. Identification of Variables}

Fundraising

\section{Independent and Moderator Variables}

Faith based organizations FBO'S

- Religious societies

- Christian Faith base organizations (FBO's)

- Muslim FBOs

- $\quad$ Islamic and international approach of fundraising

- $\quad$ Islamic Relief (IR)

Social media

- $\quad$ E-newsletters, Facebook, YouTube, Blogs, Twitter, Discussion boards 
Relationship with donors

Advanced technology tools

- $\quad$ Advanced communication technology

Joint collaboration

Tragic events

- $\quad$ Earthquake ,Disaster, flood

Special events

Philanthropy (structure and system of the organization)

\section{J. Hypotheses}

H-1: There is a significance positive relationship between donors and fundraising.

H-2: There is a significance positive relationship between social media and fundraising.

H-3: There is a significance positive relationship between special, tragic events and fundraising.

H-4: There is positive significance relationship between Street solicitation and fundraising.

Network diagram with mediating variables

\section{K. Network Diagram}

Figure 1: Fundraising dependencies and independency model

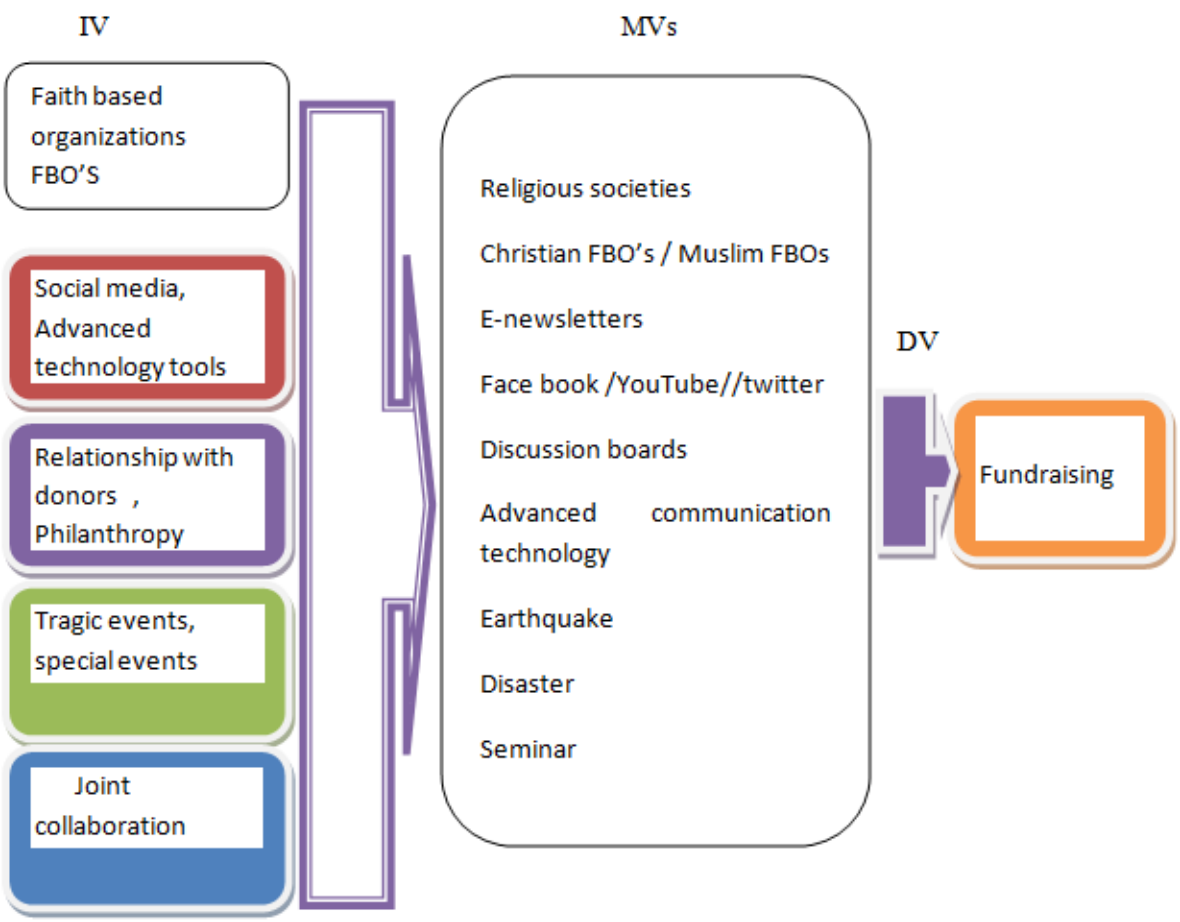

\section{Methodology}

Research method is one of the most crucial steps in every research (Ul-Hameed, Mohammad, \& Shahar, 2018; Ul-Hameed, Mohammad, Shahar, Aljumah, \& Azizan, 2019). The primary data were gathered through survey techniques from the fundraisers in the region of Punjab. A well design questionnaire was prepared so that respondents can easily answered. 
The questionnaires were filled from the president of NGO's. To get answered of the questionnaire face to face and telephonic interviews were conducted, and some questionnaires were filled through the e-mail. Sample of 125 NGO's president were selected in the 125 sample 100 respondents were responded. So, the response rate was 80 percent. From which 40 were female and 60 were male respondents. SPSS statistical software was used to analyze the questionnaire data. Frequency distribution statistical technique was used to analyze the advance fundraising technique and test the hypothesis through the SPSS software. Moreover, the reliability analysis shows Cronbach's alpha 0.720 .

\section{Findings and Discussion}

Table 1: Responses by Respondents

\begin{tabular}{|c|c|c|c|c|c|}
\hline & S. Agree & Agree & Neutral & Disagree & S. Disagree \\
\hline Proposal writing & 42 & 51 & 7 & & \\
\hline Social Media & 45 & 24 & 18 & 10 & 3 \\
\hline Special Events & 20 & 19 & 31 & 10 & 20 \\
\hline Joint Collaboration & 30 & 31 & 18 & 10 & 11 \\
\hline Sponsorship & 12 & 8 & 38 & 28 & 14 \\
\hline FBO & 13 & 3 & 26 & 21 & 5 \\
\hline Email and Phone calls & 15 & 36 & 22 & 16 & 11 \\
\hline Donor Relationship & 15 & 37 & 30 & 16 & 2 \\
\hline Online Fundraising (Bank a/c) & 19 & 22 & 27 & 19 & 13 \\
\hline
\end{tabular}

\section{Figure 2: Frequency Distribution}

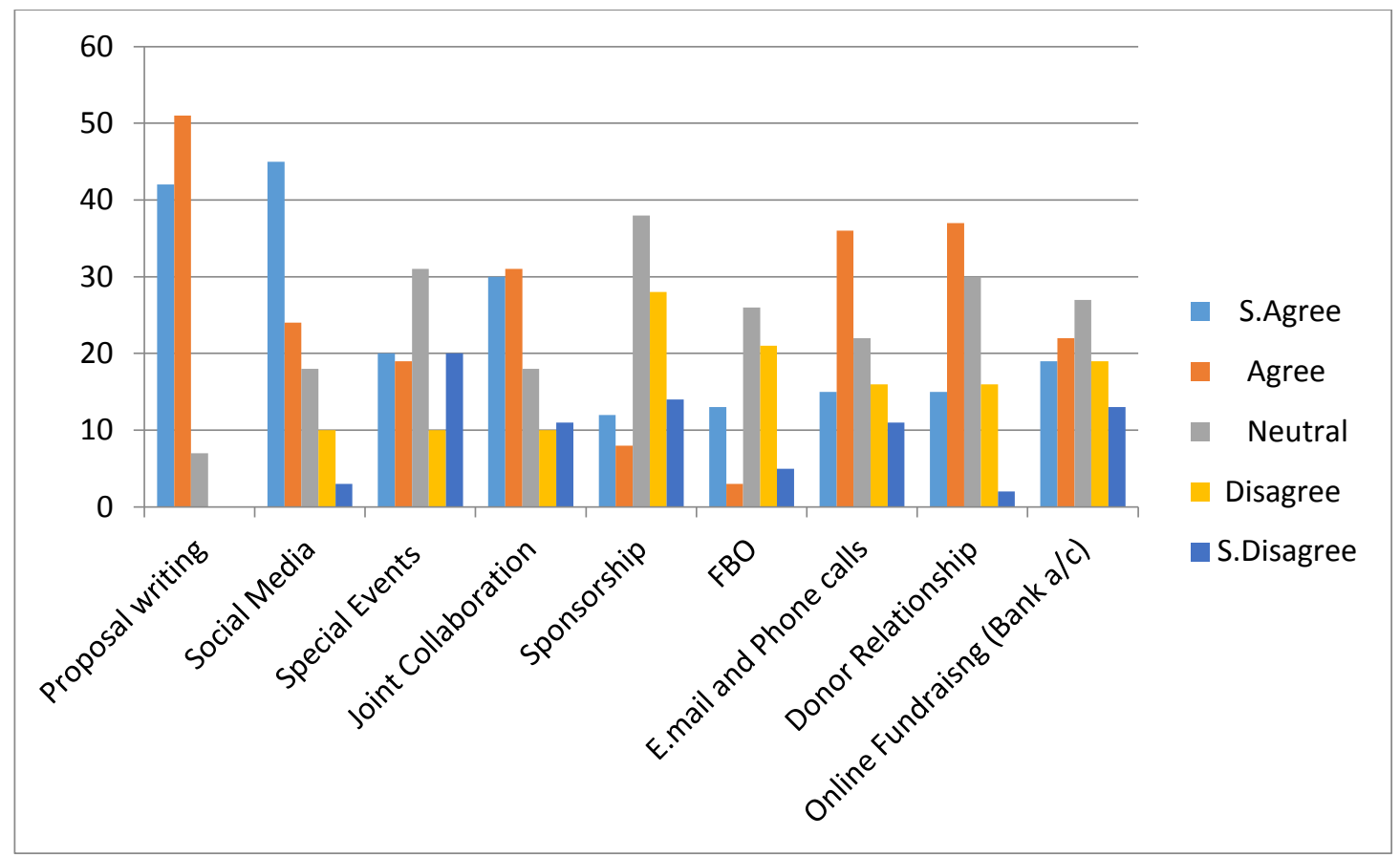


Table 2: Descriptive Statistics

\begin{tabular}{|l|c|c|c|}
\hline & $\mathbf{N}$ & Mean & Std. Deviation \\
\hline Fundraising in Punjab & 100 & 1.61 & .751 \\
\hline Fundraising through Proposal writing & 100 & 1.65 & .609 \\
\hline fundraising through email phone calls & 100 & 2.72 & 1.223 \\
\hline $\begin{array}{l}\text { social media fundraising Facebook, } \\
\text { twitter, }\end{array}$ & 100 & 2.02 & 1.146 \\
\hline Fundraising through online bank a/c & 100 & 2.85 & 1.298 \\
\hline Donor relationship with social media & 100 & 2.53 & 1.000 \\
\hline $\begin{array}{l}\text { Fundraising through Seminars , Eid } \\
\text { events }\end{array}$ & 100 & 2.91 & 1.379 \\
\hline $\begin{array}{l}\text { Fundraising in flood, disaster, earth } \\
\text { quick }\end{array}$ & 100 & 2.49 & 1.185 \\
\hline Joint.collaboration & 100 & 2.41 & 1.311 \\
\hline NGO fundraising through sponsorship & 100 & 3.24 & 1.164 \\
\hline Faith Base Organizations tor best tool for & 100 & 2.70 & 1.096 \\
\hline $\begin{array}{l}\text { Street solicitation is } \\
\text { fundraising }\end{array}$ & 100 & 2.37 & 1.079 \\
\hline $\begin{array}{l}\text { Fundraising through } \\
\text { advertisement }\end{array}$ & 100 & 2.38 & 1.173 \\
\hline $\begin{array}{l}\text { NGO is fundraising through } \\
\text { presentations to public }\end{array}$ & 100 & 2.41 & .889 \\
\hline Attract donors through advertisement & 100 & & \\
\hline Valid N (list wise) & & \\
\hline
\end{tabular}

The survey shows the different fundraisers point of view about fundraising techniques. In Fig. 2 frequency distribution shows how much percentage of fundraisers strongly agrees, agree, disagree, and strongly disagree about advance fundraising techniques. Approximately, 50\% fundraiser agrees and $40 \%$ strongly agree that donations are gathering through proposal writing. The $45 \%$ donors give donations through social media according to the NGO'S top management. The $25 \%$ to $35 \%$ respondent agrees that online fundraising through e-mail, phone calls, and joint collaboration contribute donations for nonprofit organizations. Almost 45\% respondents disagree that sponsorship contribution in NGO's funding.

Table 2 shows the descriptive statistics of the respondent answers which is taken from the SPSS analysis. Descriptive statistics measures the central tendency of the responses and tells us the variation from the mean of the responses. The mean 2.0 and below from 2.0 average respondents are agree from this fundraising technique. Moreover, more than 3.0 mean shows that average respondents are disagreeing from this fundraising technique.

\section{Conclusion}


This research concluded that social media and proposal writing are the best techniques for fundraising. Most of the fundraisers are generating fund due to these two best techniques. This research gives plate form to the fundraisers about funding. All the variables that have effect on the funding of any non-profit organization elaborately have been discussed in this research study. These variables were found from different research studies and to see the NGO's working.

In questionnaire first three questions were asked to check the donor's relationship with fundraisers. In which proposal writing, phone calls, person to person communication included. SPSS descriptive statistics and frequency distribution shows the mean of the proposal writing is 1.65 , therefore, hypothesis 1 is accepted there is the significance positive relationship between the donors and fundraisers. Social media frequency shows that $45 \%$ respondents strongly agree and $25 \%$ agree. Mean of social media question is 2.0 , therefore, the hypothesis 2 is accepted that there is a positive significance relationship between the social media and fundraising. Hypothesis 3 respondents give indifferent answers and hypothesis 4 is rejected because mean value is 3.37. Fundraisers not use this technique for funding, therefore, there is no relationship between the street solicitations.

This research study not only gives the information about advance fundraising techniques but also show the importance of social media for the charitable organization. According to the six-degree theorem everyone can contact to everyone within six steps with the help of social media.

\section{Managerial Implications}

Non-profitable organizations can increase their fund by implement the above discuss dimensions, as fundraising is a basic determinant in non-profitable organization success. Moreover, non-profitable organizations must consider the enterprise risk management (Hameed, Hashmi, Ali, \& Arif, 2017) while applying fund raising techniques. Additionally, open innovation techniques such as collaboration with partners could be more beneficial (Hameed, Basheer, Iqbal, Anwar, \& Ahmad, 2018). 
Pakistan Journal of Humanities and Social Sciences, 7(1), 2019

\section{References}

Boyer, K. E. (2011). Social Media and Nonprofits: Increasing Fundraising and Volunteerism for the Kahlo Cultural Center.

Brand, T. M. (2010). The joy of giving: an investigation of positive fundraising techniques (Doctoral dissertation, Rutgers University-Camden Graduate School).

Ciucescu, N. (2012). Financial Resources of NGOs. Studies and Scientific Researches. Economics Edition, (16-17).

Conway, D., \& Price, C. H. (Eds.). (1998). The Practice of Stewardship in Religious Fundraising: New Directions for Philanthropic Fundraising, Number 17 (Vol. 31). Jossey-Bass.

Das, E., Kerkhof, P., \& Kuiper, J. (2008). Improving the effectiveness of fundraising messages: The impact of charity goal attainment, message framing, and evidence on persuasion. Journal of Applied Communication Research, 36(2), 161-175.

Farquharson, P. E. (1994). Enhancing the Fiscal Outlook of a Nonprofit Agency through Board of Training, Fundraising Techniques and a Marketing Plan.

Foster, S., \& Robinson, J. (2012). Donor recognition and cultivation through the use of digital bookplates. Journal of Library Innovation, 3(2), 43.

Hameed, W.U., Mohammad, H.B., \& Shahar, H. K. (2018). Pursuing Goal of Self-Sustainability but Leads towards More Instability: Challenges and Way Forward of Self-Help Groups (SHGs). International Journal of Business and Tehnopreneurship, 8(1), 67-76.

Hameed, U.W., Hashmi, F., Ali, M., \& Arif, M. (2017). Enterprise risk management (ERM) system: Implementation problem and role of audit effectiveness in Malaysian firms. Asian Journal of Multidisciplinary Studies, 5(11).

Hameed, W. U., Basheer, M. F., Iqbal, J., Anwar, A., \& Ahmad, H. K. (2018). Determinants of Firm's open innovation performance and the role of R \& D department: an empirical evidence from Malaysian SME's. Journal of Global Entrepreneurship Research, 8(1), 29.

Hoefer, R. (2012). From Web Site visitor to online contributor: Three internet fundraising techniques for nonprofits. Social work, 57(4), 361-365.

Maqbool, N., Hameed, W., \& Habib, M. (2018). Impact of political influences on stock returns. International Journal of Multidisciplinary Scientific Publication (IJMSP), 1(1).

Neale, S. (2011). Fundraising by Friends of the Library Groups: Profitability Trends and Effectiveness of Recent Initiatives.

Nichols, N. (2008). Understanding the Funding Game: The TextualCoordination of Civil Sector Work. Canadian Journal of Sociology, 33(1).

Silverman, E. (2009). Inviting the donor to give. The Bottom Line, 22(4), 139-141.

Ul-Hameed, W., Mohammad, H., \& Shahar, H. (2018). Microfinance institute's non-financial services and women-empowerment: The role of vulnerability. Management Science Letters, 8(10), 1103-1116.

Ul-Hameed, W., Mohammad, H., Shahar, H., Aljumah, A., \& Azizan, S. (2019). The effect of integration between audit and leadership on supply chain performance: Evidence from UK based supply chain companies. Uncertain Supply Chain Management, 7(2), 311-328.

Unerman, J., \& O'Dwyer, B. (2006). Theorising accountability for NGO advocacy. Accounting, Auditing \& Accountability Journal, 19(3), 349-376.

Waters, R. D. (2010). The Value of Relationship and Communication Management in Fundraising: Comparing Donors' and Practitioners' Views of Stewardship. 